\title{
Radiofrequency Ablation of Benign Thyroid Nodule
}

\author{
Chang Ki Yeo \\ Department of Otolaryngology-Head and Neck Surgery, School of Medicine, Keimyung University, Daegu, Korea
}

\section{갑상선 양성결절의 고주파 치료}

\author{
여 창 기 \\ 계명대학교 의과대학 이비인후과학교실
}

\author{
Received November 28, 2013 \\ Accepted January 13, 2014 \\ Address for correspondence \\ Chang Ki Yeo, MD \\ Department of Otolaryngology- \\ Head and Neck Surgery, \\ School of Medicine, \\ Keimyung University, \\ 56 Dalseong-ro, Jung-gu, \\ Daegu 700-712, Korea \\ Tel +82-53-250-7711 \\ Fax +82-53-256-0325 \\ E-mail ckyeo@dsmc.or.kr
}

\begin{abstract}
Radiofrequency ablation (RFA) is not only a procedure used in treating malignant liver tumors, but is also a valuable way of treating benign thyroid nodules. RFA can be used in almost every patient, regardless of the contents of the solid component. One of the merits of RFA is that it may be used as an alternative to benign thyroid nodule surgeries. With this method, patients who so only choice in the past were to get surgeries can be treated in another way. This article reviews the indications, pre-procedural evaluations, techniques, results, and complications of thyroid radiofrequency ablation. Korean J Otorhinolaryngol-Head Neck Surg 2014;57(3):151-4
\end{abstract}

Key Words Radiofrequency · Thyroid · Ultrasonography.

\section{서 론}

갑상선암의 치료에 있어 수술적 치료는 이견이 없다. 하지만 갑상선 양성결절은 크기가 크지 않을 때는 대부분 일정기간 추적관찰을 하며 크기가 커서 미용적 문제, 증상이 있을 경우 에는 갑상선 호르몬 억제요법 또는 수술을 시행한다. 하지만 이러한 억제요법은 갑상선 양성결절을 치료하는 데 효과적인 방법은 아니며 치료 결과 또한 만족할 만하지 못하고, 수술은 절개선의 흥터 등 미용적인 문제와 일부 환자에서 술 후 갑상 선 기능저하증으로 갑상선 호르몬제를 복용해야 하는 불편함 이 있다. 최근에는 이러한 갑상선 양성결절의 치료에 비침습적 방법인 고주파 열에너지를 이용한 치료가 시행되고 있으며 수 술적 치료와 함께 갑상선 양성결절을 치료하는 또 하나의 방 법으로 알려져 있다. 고주파 장치는 단극 방식(monopolar system)과 양극 방식(bipolar system)이 있으며 단극 방식은 활 성 전극과 접지판 사이를 전자기파가 흐르게 되며, 양극 방식은 별도의 접지판이 필요하지 않고 전파가 전극의 끝에 0.5 1.0 $\mathrm{cm}$ 간격으로 활성과 비활성 전극이 위치하며 이를 통해 조직 에 열을 발생시키게 된다(Fig. 1). 고주파열 치료는 처음에는
간암을 치료하는 데 시도되어 좋은 결과를 얻었으며 최근 이 비인후과 영역에는 하비갑개수술, 편도수술, 코골이 수술에 활 용되고 있다. 갑상선 양성결절의 치료에 고주파 치료를 함으로 써 치료시간의 단축, 불필요한 절개선을 피할 수 있고 전신마 취의 번거로움 또한 피할 수 있다. 이에 저자는 여러 문헌 고찰 을 바탕으로 고주파 치료의 적응증, 시술 전 검사, 시술방법, 효과, 안정성 및 장점을 알아보고 고주파를 이용한 갑상선 양 성결절의 치료에서 이비인후과 의사의 역할에 대해 알아보 고자 한다.

\section{본 론}

\section{적응증}

갑상선 고주파 치료는 증상이 있는 갑상선 양성결절 및 수 술이 곤란한 재발 갑상선암 및 임파선 전이에 제한적으로 적 용할 수 있으며, 여포종양 및 갑상선암의 초치료에는 적용하 지 않는다. 임산부에서 주의해야 하며 고주파의 특성으로 인 해 심각한 심장계통 질환이 있거나 반대측 성대마비가 있는 환자에서는 주의를 요한다. 양성결절 때문에 증상이 있거나 미 
용적인 문제, 기능항진증을 동반한 결절, 알코올 경화 요법 후 재발한 경우 고주파 치료의 적응증이 된다. 재발한 갑상선암 의 치료 원칙은 수술이나 수술의 위험도가 높고 수술을 거부 한 환자에서 이차적인 치료 방법으로 사용될 수 있다.

\section{시술 전 검사(Pre-procedural evaluation)}

양성결절의 고주파 치료를 위해서는 먼저 최소 두 번의 세침 흡인검사(FNA)에서 양성 판정이 되어야 한다(Table 1). 이때 주의할 점은 세침검사에서 양성 판정이 되어도 초음파 소견에 서 악성의 소견이라면 고주파 치료를 시행하지 않아야 한다. 시술 전 초음파 검사를 통해 결절의 크기, 특성, 고형성분과 낭 (cyst)의 비율을 확인하여야 한다. 즉, 혼합병변일 경우 고형성 분이 $20 \%$ 이상인 결절은 고주파 치료의 대상이 된다. 결절의 부피는 $\mathrm{V}=\pi \mathrm{abc} / 6$ 의 공식으로 구할 수 있으며 $\mathrm{a}, \mathrm{b}, \mathrm{c}$ 는 각각 장경 및 가로, 세로의 길이를 의미한다. 혈액 검사는 일반혈액 검사 $(\mathrm{CBC})$ 와 혈액응고 검사뿐 아니라 갑상선 기능검사 $[\mathrm{TSH}$, free T4, T3, thyroglobulin(TG), anti TG-Ab] 및 칼시토닌 검 사가 필요하다. 시술 전 환자가 항응고제를 복용하고 있다면 시술 전 아스피린은 7 10일, 와파린은 3 5일, 헤파린은 4 6시 간 중단 할 것을 권한다. 고주파 치료 후 헤파린은 2 6시간 후, 와파린은 그 날 저녁부터, 아스피린은 시술 다음날부터 다시 복용하면 된다. 특히 갑상선 기능항진증이 의심된다면 ${ }^{99 \mathrm{~m}} \mathrm{Tc}-$ pertechnetate 또는 ${ }^{123} \mathrm{I}$ thyroid scan을 권한다. 갑상선 항체가 증가되어 있다면 고주파 치료 후 갑상선 기능저하증의 가능성 을 설명하여야 한다. ${ }^{23)}$ 재발한 갑상선암의 고주파 치료를 위 해서는 초음파 유도하 세침검사에서 암이 확진되어야 하며 그 외의 검사는 양성결절과 동일하다. 시술 전 적어도 6 시간은 금 식이 필요하다. 고주파 시술 전 동의서 서명은 필수이며 아래
의 내용이 반드시 포함되어야 한다. 1) 고주파 시술 후 결절은 수개월에서 일년에 걸쳐 서서히 줄어든다. 2) 대부분의 결절은 한 번의 고주파 치료로 효과가 있으나 크기가 큰 경우 2회 이 상 시행할 수 있다. 3) 고주파 치료 후 결절이 다시 커지는 경우 도 있다. 4) 시술 중 통증이 동반된다. 5) 시술 후 발생할 수 있 는 합병증 등이다.

\section{시술 방법, 모니터링 및 추적관찰}

시술 방법은 필요에 따라 시술 30 분 전 수면제 또는 안정제 의 혈관투여를 하기도 하며 시술 부위에 국소마취를 한 후 고 주파 전극이 쉽게 삽입되도록 피부에 $2 \mathrm{~mm}$ 정도 절개를 한 다. 전극의 위치는 결절 피막에서 $10 \mathrm{~mm}$ 정도 떨어져야 하며 경부 주위 구조물과는 안전을 위해 적어도 $15 \mathrm{~mm}$ 정도 떨어 져 있는 게 좋다. 결절의 크기가 큰 경우는 절개선을 두 군데 넣어 결절의 상하로 접근하기도 한다. 시술이 끝난 후 절개선 은 피부 반창고(steri-strip)를 이용하면 충분하며 반흔이 생 기지 않는다. ${ }^{2,4)}$

고주파 시술시 전극의 움직임을 최소화하기 위하여 'transisthmic approach'가 좋으며 전극을 한 곳에 고정시키지 말고 결절 내에서 움직이며 치료하는 'moving shot technique'이 일 반적인 방법이다(Fig. 2). ${ }^{5)}$ 시술 중 혈압, 맥박을 확인하며 환자 와의 대화를 통한 목소리 변화를 확인하여 목소리 변화가 있 으면 시술을 즉각 중지한다.

초음파를 이용하여 시술 중 캡슐 하 혈종 및 출혈을 확인하 며 출혈이 심할 경우 시술을 중지하고 즉시 압박한다. 대부분 의 혈종은 2 주 내 자연 흡수된다. 시술 중 고주파 열로 인한 통증이 발생할 수 있으며, 이는 시술 중 발생되는 전극의 $90^{\circ} \mathrm{C}$ 되는 높은 열로 인해 생기며 파워를 조정하거나 시술을 일시

Fig. 1. The radiofrequency unit (Coblator II)(A). Patient's position (B).
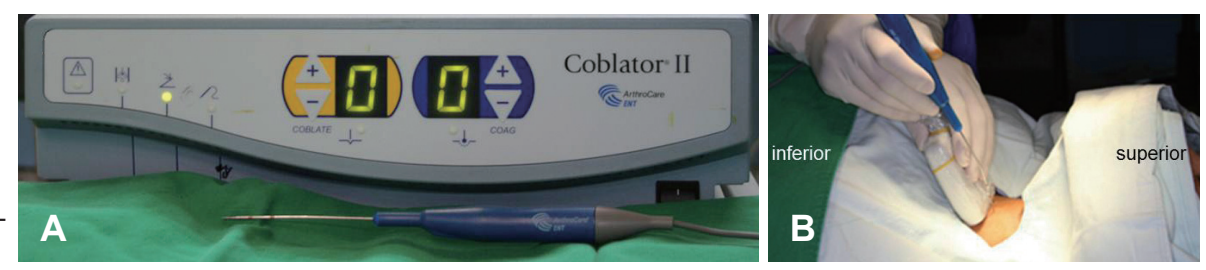

Table 1. Preprocedural check points for radiofrequency ablation

\begin{tabular}{ll}
\hline Benign thyroid nodule & Recurrent thyroid cancer \\
\hline Benign cytologic diagnosis (at least two times) & Cytologic diagnosis \\
Ultrasound feature & Ultrasound feature \\
Nodule volume & Tumor volume \\
Symptom (dysphagia, discomfort) & \\
Cosmetic problem & \\
Laboratory test & Laboratory test (Tg, Tg-Ab) \\
CT or MRI if needed & $\mathrm{CT}$ if needed \\
${ }^{99 m}$ Tc-pertechnetate or ${ }^{123}$ I thyroid scan if automatic functional nodule & \\
\hline CT: computed tomography, MRI: magnetic resonance imaging, Tg-Ab: thyroglobulin antibody
\end{tabular}


중지함으로써 소실된다. 기존의 전기소작기(bovie)를 이용한 조직 소작시 $500^{\circ} \mathrm{C}$ 의 고열이 발생되는 것에 비하면 고주파를 이용한 조직 소작술은 주위 조직에 대한 열손상이 상대적으 로 적은 장점이 있다. ${ }^{1)}$ 시술 중 보조의사는 환자의 피부 화상, 오심, 구토, 호흡곤란, 애성 등을 모니터링 하여야 한다. 시술 후 진통제 및 스테로이드 경구 요법이 증상 완화에 도움이 된 다. 추적관찰은 고주파 치료 후 1 개월, 6 개월, 12 개월에 함을 원칙으로 하며, 그 후 1 년마다 추적관찰을 권한다.

\section{고주파 치료의 효과}

양성결절의 치료 효과는 증상의 완화, \%부피 감소 정도[(시 술 전 부피-시술 후 부피 $\times 100$ /시술 전 부피], 치료 성공률 (50\% 이상의 부피감소)로 판단한다. 도플러 초음파를 이용하 여 시술 후 결절 내 혈관음영이 있다면 고주파 치료가 안된 부 분을 의미한다(Fig. 3). 재발한 갑상선암의 치료효과는 \%부피 감소 정도와 혈청 $\mathrm{TG}$ 농도를 측정하여 확인한다. 고주파 시술 후 처음 24 시간 안에 열응고에 의한 급성염증 반응이 나타나며, 시술 3일 후 조직의 괴사가 진행되고, 10 일 후부터 섬유화와 반 흔 조직으로 변해간다. 부피감소는 크게 2단계로 이루어지게 되 며, 1단계는 정상조직이 반흔 조직으로 바뀌면서 주위 조직을 끌어당기는 단계이고, 2 단계는 수개월에 걸친 반흔, 섬유조직

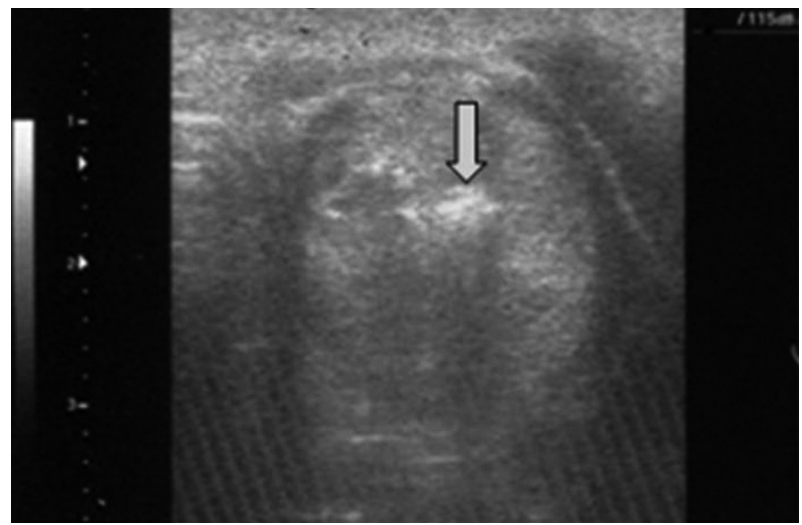

Fig. 2. Axial sonographic view shows that nodule was filled with echogenic microbubble at end of ablation (arrow: echogenic microbubbles).
의 흡수에 따른 2 차적인 부피 감소이다. ${ }^{2,6)}$

갑상선 양성결절의 치료에 고주파 치료 이외에 레이저 치료 가 사용되기도 한다. ${ }^{5,8)}$ 고주파 치료 후 부피감소는 첫 1 개월째 $33 \sim 58 \%, 6$ 개월째 51 92\%의 효과를 나타낸다. ${ }^{2)}$ 다른 연구 결 과에 의하면 술 전, 술 후 $1,3,6$ 개월의 부피측정에서 술 전 27.7 $\pm 21.5 \mathrm{~mL}$ 이고 1 개월째 $19.2 \pm 16.2 \mathrm{~mL}$ 3개월째 $15.9 \pm 14.1 \mathrm{~mL}$, 마지막 6 개월째 $14.6 \pm 12.6 \mathrm{~mL}$ 로 감소하였다. ${ }^{4.9)}$ 추적관찰 중 부피감소율(volume reduction ratio)이 $50 \%$ 이하이거나 시술 후 초음파에서 결절 내 증가 된 혈관 음영이 보일 경우 2차 고 주파 치료의 적응증이 되며, 초치료시에도 결절의 부피가 20 $\mathrm{mL}$ 이상인 경우는 2 차 고주파 치료가 필요할 수 있다. ${ }^{10,11)}$ 재발 한 갑성선암의 고주파 치료 성적은 암의 부피 감소율은 56 93\% 이며, 42 58\%에서 결절의 소실을 보이며, $64 \%$ 의 환자가 증상 완화 및 시술 후 $\mathrm{TG}$ 감소를 보인다. 전이된 갑상선암은 수술적 절제가 원칙이나 고주파 치료는 수술이 불가능할 경우 사용할 수 있는 방법이다. ${ }^{5,12-14)}$

\section{에탄올 경화요법과 고주파 치료의 비교}

고형성분이 없는 갑상선 낭종의 치료에 있어서 에탄올 경화 요법이 고주파 치료보다 간편하고 비용면에서 우수하므로 순 수 갑상선 낭종인 경우는 에탄올 경화요법을 먼저 시도하는 것이 좋다. ${ }^{15)}$ 보통 에탄올 경화요법의 치료실패율은 5 25\%로 알려져 있다. ${ }^{16)}$ 또 다른 연구에서는 고체성분이 $20 \%$ 이상인 결 절의 경우 에탄올 경화요법보다는 고주파 치료가 훨씬 효과 있 다는 보고가 있다. ${ }^{17)} 20 \%$ 이상의 고체 성분을 가진 결절은 에 탄올 경화요법만 시행할 경우 $50 \%$ 이상에서 재발하므로 먼저 액체 성분을 흡인한 후 결절 내 생기는 출혈을 예방하기 위해 $99 \%$ 에탄올을 주입하여 2분간 기다려 지혈한 후 주입한 에탄 올을 다시 흡인하여 제거한 후 고주파 치료를 함으로써 치료 성공률을 높일 수 있다. ${ }^{18)}$

\section{안정성 및 합병증}

고주파 치료의 흔한 합병증으로는 통증, 출혈, 애성, 피부화 상, 기능저하증, 기능항진증, 감염 및 결절의 파열(rupture) 등
Fig. 3. The untreated remaining solid component shows internal vascularity (arrow). Doppler view (A). Axial sonographic view (B).
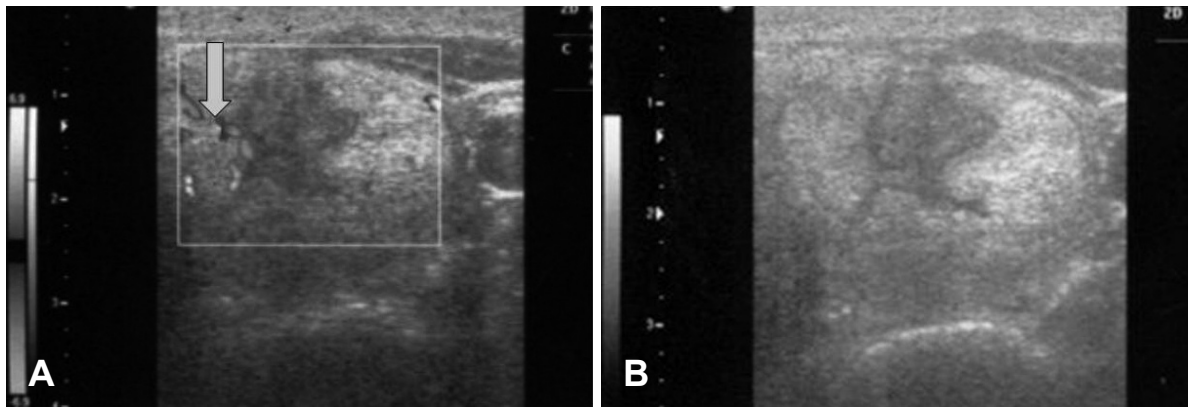
Table 2. Complications and side effects of thyroid radiofrequency ablation

\begin{tabular}{|c|c|c|}
\hline $\begin{array}{c}\text { Major } \\
\text { complications }\end{array}$ & $\begin{array}{c}\text { Minor } \\
\text { complications }\end{array}$ & $\begin{array}{c}\text { Side } \\
\text { effects }\end{array}$ \\
\hline Voice change & Hematoma & Pain \\
\hline Nodule rupture & Vomiting & Vasovagal reaction \\
\hline $\begin{array}{r}\text { Nodule rupture } \\
\text { with abscess }\end{array}$ & Skin burn & Coughing \\
\hline \multicolumn{3}{|l|}{ Hypothyroidism } \\
\hline Brachial plexus injury & & \\
\hline
\end{tabular}

이 있다(Table 2). 합병증의 빈도는 약 $3.3 \%$ 정도이며, 이 중 통 증(2.6\%), 혈종(1.02\%) 및 애성(1.02\%)이 가장 흔한 합병증이 다. 통증은 시술 중 고주파 세기를 조절하고 시술을 일시 중단 함으로써 완화시킬 수 있다. 애성은 시술 중 되돌이 후두신경 의 손상으로 나타나며 대부분 일시적이며 대개 3 개월 뒤 회 복된다. ${ }^{19)}$ 혈종도 시술 후 압박으로 완화되며 대부분 1 2주 후 자연 흡수된다. 혈종을 예방하기 위하여 초음파 하 전극의 위 치를 항상 확인하며 시술하여야 한다. 시술 후 갑상선 기능의 변화가 생길 수 있으며 대부분 1 개월 내 정상화된다. 그 외, 심 각한 합병증으로 기도 손상이 올 수 있으며 이를 예방하기 위 하여 환자가 시술 중 기침이 심할 때에는 시술을 일시적으로 멈추어야 한다. ${ }^{20)}$

\section{결 론}

갑상선 양성결절에 있어 갑상선 고주파 치료는 시술시간의 단축, 국소마취, 흥터의 소실 및 외래에서 시술 가능한 점 등 수술에 비해 장점이 있다. 갑상선 양성결절 중 일부와 수술의 합병증이 크거나 수술 자체를 거부하는 재발 갑상선암 환자에 서 고주파 치료는 유용한 대안으로 제시될 수 있다. 이비인후 과 의사들은 초음파, 세침흡인검사, 고주파 치료기(coblator)에 익숙하므로 갑상선 양성결절을 가진 환자들을 치료할 때 갑 상선 수술뿐 아니라 고주파 치료를 통해서도 양성결절은 치 료할 수 있음을 설명하는 것도 환자에게 도움이 되리라 생각 된다.

\section{REFERENCES}

1) Kim JH. Radiofrequency surgery. Korean J Otolaryngol-Head Neck Surg 2002;45(6):531-7.

2) Na DG, Lee JH, Jung SL, Kim JH, Sung JY, Shin JH, et al. Radiofrequency ablation of benign thyroid nodules and recurrent thyroid cancers: consensus statement and recommendations. Korean J Radiol 2012;13(2):117-25.

3) Baek JH, Moon WJ, Kim YS, Lee JH, Lee D. Radiofrequency ablation for the treatment of autonomously functioning thyroid nodules. World J Surg 2009;33(9):1971-7.

4) Deandrea M, Limone P, Basso E, Mormile A, Ragazzoni F, Gamarra
E, et al. US-guided percutaneous radiofrequency thermal ablation for the treatment of solid benign hyperfunctioning or compressive thyroid nodules. Ultrasound Med Biol 2008;34(5):784-91.

5) Baek JH, Lee JH, Valcavi R, Pacella CM, Rhim H, Na DG. Thermal ablation for benign thyroid nodules: radiofrequency and laser. Korean J Radiol 2011;12(5):525-40.

6) Baek JH, Kim YS, Lee D, Huh JY, Lee JH. Benign predominantly solid thyroid nodules: prospective study of efficacy of sonographically guided radiofrequency ablation versus control condition. AJR Am J Roentgenol 2010;194(4):1137-42.

7) Ritz JP, Lehmann KS, Schumann T, Knappe V, Zurbuchen U, Buhr $\mathrm{HJ}$, et al. Effectiveness of various thermal ablation techniques for the treatment of nodular thyroid disease--comparison of laser-induced thermotherapy and bipolar radiofrequency ablation. Lasers Med Sci 2011;26(4):545-52.

8) Pacella CM, Bizzarri G, Spiezia S, Bianchini A, Guglielmi R, Crescenzi A, et al. Thyroid tissue: US-guided percutaneous laser thermal ablation. Radiology 2004;232(1):272-80.

9) Holmer C, Lehmann KS, Knappe V, Zurbuchen U, Frericks B, Schumann T, et al. Bipolar radiofrequency ablation for nodular thyroid disease--ex vivo and in vivo evaluation of a dose-response relationship. J Surg Res 2011;169(2):234-40

10) Jeong WK, Baek JH, Rhim H, Kim YS, Kwak MS, Jeong HJ, et al. Radiofrequency ablation of benign thyroid nodules: safety and imaging follow-up in 236 patients. Eur Radiol 2008;18(6):1244-50.

11) Huh JY, Baek JH, Choi H, Kim JK, Lee JH. Symptomatic benign thyroid nodules: efficacy of additional radiofrequency ablation treatment session--prospective randomized study. Radiology 2012; 263(3):909-16.

12) Baek JH, Kim YS, Sung JY, Choi H, Lee JH. Locoregional control of metastatic well-differentiated thyroid cancer by ultrasoundguided radiofrequency ablation. AJR Am J Roentgenol 2011;197(2): W331-6.

13) Monchik JM, Donatini G, Iannuccilli J, Dupuy DE. Radiofrequency ablation and percutaneous ethanol injection treatment for recurrent local and distant well-differentiated thyroid carcinoma. Ann Surg 2006;244(2):296-304

14) Dupuy DE, Monchik JM, Decrea C, Pisharodi L. Radiofrequency ablation of regional recurrence from well-differentiated thyroid malignancy. Surgery 2001;130(6):971-7.

15) Sung JY, Kim YS, Choi H, Lee JH, Baek JH. Optimum first-line treatment technique for benign cystic thyroid nodules: ethanol ablation or radiofrequency ablation? AJR Am J Roentgenol 2011; 196(2):W210-4.

16) Lee JH, Kim YS, Lee D, Choi H, Yoo H, Baek JH. Radiofrequency ablation (RFA) of benign thyroid nodules in patients with incompletely resolved clinical problems after ethanol ablation (EA). World J Surg 2010;34(7):1488-93.

17) Jang SW, Baek JH, Kim JK, Sung JY, Choi H, Lim HK, et al. How to manage the patients with unsatisfactory results after ethanol ablation for thyroid nodules: role of radiofrequency ablation. Eur J Radiol 2012;81(5):905-10.

18) Yoon HM, Baek JH, Lee JH, Ha EJ, Kim JK, Yoon JH, et al. Combination Therapy Consisting of Ethanol and Radiofrequency Ablation for Predominantly Cystic Thyroid Nodules. AJNR Am J Neuroradiol 2013. [Epub ahead of print]

19) Ha EJ, Baek JH, Lee JH, Kim JK, Shong YK. Clinical significance of vagus nerve variation in radiofrequency ablation of thyroid nodules. Eur Radiol 2011;21(10):2151-7.

20) Shin JH, Baek JH, Oh YM, Ha EJ, Lee JH. Combination therapy of temporary tracheal stenting and radiofrequency ablation for multinodular thyroid goiter with airway compression. Korean J Radiol 2013;14(5):805-9. 